\title{
Human Security and the Rise of Global Therapeutic Governance
}

Vanessa Pupavac, School of Politics, University of Nottingham, Nottingham NG3 2RD, vanessa.pupavac@ nottingham.ac.uk

A final version of this article appeared as follows Vanessa Pupavac 'Human Security and the Rise of Global Therapeutic Governance.' Conflict, Security and Development, Vol 5 (2), 2005, pp. 161-181.

This article discusses the emergence of global therapeutic governance or the influence of social psychology on international development policy. Therapeutic governance links psychosocial well-being and security, and seeks to foster personalities able to cope with risk and insecurity. The article analyses how Western alarm at the destabilising impact of development eroded its support for an industrialisation model of development. The article then examines how the basic needs model is underpinned by social psychological theories and involves an abandonment of national development. Finally the article considers development as therapeutic governance and the implications of abandoning national development for the concept of human security.

\section{Introduction}

The World Health Organisation (WHO) recently declared mental illness to be one of the major health concerns for the twenty-first century, but it is not only health organisations which are interested in the subject. Mental well-being of populations is attracting wider attention among international policy-makers from the World Bank to the Department of International Development (DFID). This article considers the emergence of global therapeutic governance or the influence of social psychology on international development policy. What do I mean by therapeutic governance? Therapeutic governance refers to management of populations' psychology, and its significance for security. Therapeutic governance makes a link between psychosocial well-being and security, and seeks to foster personalities able to cope with risk and insecurity. So an individual's sense of psychosocial well-being is not simply of personal concern, but is an aspect of good governance.

The emergence of therapeutic governance is linked to development's demise and absorption into security as human security. ${ }^{1}$ Human security has been promoted by proponents as broadening our approach to security and as a belated corrective to statecentric security Against conflation of security with the state, the concept is used to distinguish state security and individual security. The concept recognises how security should not be reduced to the security of the state and that security is ultimately about protecting individuals. The concept is further invoked to challenge assumptions over the state providing security and to highlight how the state is too often a violator of individuals' security. The concept of human security has taken off among international organisations and among Western donor states. Notably Canada and Japan as donor countries have been prominently involved in elaborating the concept, Canada primarily in relation to humanitarian intervention (Axworthy, 1999) and Japan primarily in relation to its development aspects (Obuchi, 1999). The United Nations Development Programme (UNDP) within the UN system has been most 
closely associated with promoting the concept in its work, notably in its 1994 annual human development report on New Dimensions of Human Security. Despite its evident appeal, the concept of human security has been criticised as a rather vague concept, at once encompassing everything but thereby becoming meaningless (King and Murray, 2001-2002; Mack, 2004). Its appeal is seen as rhetorical and of limited practicability. I concur with various criticisms made of the concept of human security. Nevertheless, the concept is politically significant, its attraction related to the demise of national development and the developing state. Here I am primarily concerned with the development aspects of human security, but its military humanitarian agenda, questioning the capacity of the developing state to protect its population, arises logically from the changed international development agenda.

From the development perspective, the concept of human security essentially represents an attempt to salvage a demoralised development agenda by harnessing itself directly to the security field. Although proponents of the concept see human security as broadening international security, such an understanding overlooks how international development's establishment as a subject and policy area represented a broad international security approach. The rise of international development was bound up with international security policies, conditioned by the balance of power and the security concerns of the major powers, notably the United States. Western states' support for international development has historically been qualified by fears of its destabilising impact on societies and only supported in so far as it is regarded as furthering international order. Indeed the very concept of development has been analysed as meaning 'ordered progress' and its history bound up with the security context (Cowen and Shenton, 1995; Duffield, 2001). Importantly, however, the Cold War security paradigm allowed international development to evolve as a field relatively independent of security. Development's independent path represented a broader, more optimistic international agenda; development's re-incorporation into security signals a narrower, pessimistic agenda. Anticipating my argument, if development has previously involved strategies reconciling order and progress, today's development model involves reconciling people to a world without expectations of material progress. The contemporary outlook essentially seeks to improve people's sense of well-being in the absence of material transformation by reforming the subjectivity of populations, that is a form of therapeutic governance. In other words, the broadening of security denotes expansion of security measures and contraction of the developmental agenda.

The article highlights how ideas from social psychology have influenced how development thinking has responded to security concerns. I begin by analysing how the Cold War promoted consensus over international development and Western support for modernisation. I next examine how Western alarm at the destabilising impact of development eroded support for an industrialisation model of development and informed the basic needs model. I then examine how the basic needs model is underpinned by social psychological theories and involves an abandonment of national development. Finally I consider development as therapeutic governance and the implications of abandoning national development for the concept of human security.

\section{International development and Cold War security}


International development policy was born in the context of national independence struggles and Cold War competition between the Western and Soviet blocs for influence in the newly independent states. A core concern of Western policy-makers was the destabilising impact of weak pre-industrial states on an international order based on the principle of states guaranteeing their own security. Another key concern was securing the new states to the Western bloc. How could the newly independent states be developed so that they were stable states without becoming new security threats to the West, whether in their own right or by coming under Soviet influence? Western thinking was underpinned by racial fears of the international balance of slipping from Western nations with the ascendancy of formerly subject peoples in Asia and Africa, including demographically, although such racialised thinking had become unacceptable to express internationally (Furedi, 1997, 1998). These fears built on fears of the masses and their new political role in the mass societies created through industrialisation, urbanisation and the erosion of tradition, which the new science of social psychology sought to address (Dollard et al, 1938; Gasset, 1961; LeBon, 1995). Conversely Western thinking was conscious of 'The Choice' that developing countries enjoyed internationally (Galbraith, 1964, p. 23). Policy-advisors repeatedly warned of competing with the Soviets for the hearts and minds of the South and the need to outline "what we have to offer the developing country as compared with the Communists' (ibid., p. 24). Indicative of the security preoccupations underlying economic development policy, Walt Rostow's famous treatise on The Stages of Economic Growth is subtitled A Non-Communist Manifesto. Consequently Western qualms over development's potential to destabilise the existing international order were suppressed by concerns that if the West did not promote a development programme for industrialisation then the new states would turn communist. The Western model of modernisation was to promote Westernisation and secure the developing countries to the Western bloc. Indicatively US capital investment was concentrated on regions such as Asia-Pacific which were considered important strategically.

Thus Cold War rivalry, although involving ideologically divergent visions, fostered international consensus over the necessity of development. Ironically the Cold War climate allowed international development thinking to evolve a path distinct from security policy to a greater degree than the post-Cold War era. Western policymakers, having accepted the necessity of promoting economic development, hoped that reducing the economic development gap between states would also reduce ideological differences and promote international consensus around the values of the advanced Western industrial states (Etzioni, 1962, p. 203). Development thinking complimented Western postwar domestic policy, which drew political legitimacy from economic prosperity and the model of the citizen as a consumer. Citizens' loyalty was to be engineered through appealing to their unconscious, irrational desires and promoting their identification with the mass consumer products of capitalism (Bernays, 1956).

International economic development goals were initially ambitious and meant the industrialisation of the newly independent states, designated developing countries. Development thinking revolved around the difficulties of generating economic takeoff and urban industrial development; questioning whether it should be pursued was not acceptable internationally. Industrialisation was also considered essential for realising social justice, not opposed to it. This view was not confined to the Bretton 
Wood institutions, but was also held by international welfare organisations such as UNICEF as the leading international child agency which regarded policies prioritising national economic growth as compatible with child welfare concerns (UNICEF, 1964).

\section{Becoming Modern?}

In practice however developing countries found it difficult to secure large capital investment from the West unless like Japan or Taiwan they were viewed as important strategically in the Cold War. While the invisible hand of the market failed to generate capital, Western aid policy seemed to favour technical assistance (Galbraith, 1964 , p. 58). To compensate for the lack of external capital, local investment was to be maximised by limiting population growth and improving peoples' skills and productivity. In this endeavour, Western modernisation strategists asked whether cultural change was a prerequisite of modernisation (Ikeles, and Smith, 1974, p. 9). It was suggested people's aspirations needed to be raised to foster the demand for economic growth. Rostow argued that 'the horizon of expectations must lift; and men must become prepared for a life of change and specialized function' (Rostow, 1971, p. 26). Works such as David McClelland's The Achieving Society sought to identify the 'mental virus' that drives people to achieve and therefore promote economic growth, and to train people to 'infect' others with the need to achieve. Again the economist J.K. Galbraith wanted to tackle 'the equilibrium of poverty', that is, the poor's accommodation to poverty, their 'absence of aspiration' and 'the tendency to prefer acquiescence to frustration' (Galbraith, 1979, pp. 61-62). Literacy, Galbraith proposed, could be used as a tool for raising aspirations (Galbraith, 1964, pp. 42-46).

Accordingly international development policy from its inception has been interested in the psychology of populations. Yet the cultural and personal traits viewed as desirable in Western thinking have changed considerably. Sixty years ago the desirable character to be cultivated was the rational ambitious mature masculine ego, inoculating the individual against the perceived irrationalism of mass society as well as challenging the atavistic remnants of traditional society. This conception of the ideal citizen as an ambitious masculine moderniser contrasts sharply with today's sustainable development ideal of the emotionally sensitive, modest female personality living in equilibrium with nature.

But even as the ideal of the modern personality was being championed, anxieties over the destabilising impact of development remained in Western thinking, notably in the culture and personality school of anthropology centred at the University of Columbia spearheaded by the work of Ruth Benedict and Margaret Mead. Their research consciously eschewed the earlier racial thinking, which propounded the pathological condition of the deracinated native. Indeed their anthropological research into nonWestern societies was partly driven by their doubts over the character of Western civilisation and prevailing Western notions of progress (Benedict, 1961, for example). These concerns over their own societies in turn informed their concerns over the risks to the personality of populations undergoing rapid political, social and economic change. Research concerned with the functionality of the non-Western culture and personality in circumstances of rapid change remained an important strand of Western thinking as an adjunct to Western security policy, particularly in relation to the strategically important areas of Asia. Publications on the Third World mind, notably 
in Asian countries, and the difficulty of nation building and promoting a democratic political culture were a staple theme in Western area studies and political science literature influenced by social psychology.

Psychosocial risk studies sought to evaluate the risk factors for Third World revolution and could provoke international controversy, most vividly testified in the scandal over the aborted Camelot project (Herman, 1995, pp. 124-173). Psychosocial perspectives were marginalised within international development policy, which embraced rapid economic growth in the 1950s and 1960s. The psychosocial perspectives were also marginal in peace studies which was dominated by structural approaches too rather than approaches from social psychology which informed conflict studies. Indeed Johan Galtung, a leading figure in peace studies, helped expose the Camelot project (ibid.), illustrating how the general international climate in peace and development studies was hostile to psychosocial risk analysis of developing countries. So although other US risk analysis projects did quietly go ahead these projects were not well received internationally. These concerns were surfaced in subsequent decades.

\section{Problems of the Affluent Society}

Early international development thinking saw rural poverty as the great evil to be eradicated. Urban poverty however visible was regarded in the optimistic progressive outlook as a lesser evil to rural poverty and a condition whose extremes were a transitory feature of a dynamic industrialising economy - moreover one that also provided its own checks. For mobile urban populations had greater expectations of well-being and opportunities for political engagement, and therefore to articulate and defend their interests. But the very advantages that the urban poor enjoyed over their rural cousins also raised the spectre of political radicalisation and social instability. Policy-makers had followed modernisation's impact on societies from the inception of international development policy. Large international conferences were held in the 1950s, prominently the United Nations/UNESCO 1956 seminar on urbanisation in Asia and Middle East and the United Nations/UNESCO 1959 on urbanisation in Latin America. Urbanisation studies repeatedly warned that although urbanisation was happening (cities were growing), urbanism (the adoption of urban norms) was not (Nelson, 1969; Ginsburg, 1966). Achieving a sense of identity was more difficult and perplexing in an urban world, it was argued (Wood, 1966, p. 51). The social atomization of urban life fostered alienation and anxiety in individuals leading them to seek release in violence (Kornhauser, 1960, p. 32). Modernisation and the erosion of traditional ties exposed the worker to 'new forms of gratification' resulting in 'confusions and disorientations' (Smelser, 1966, p. 123). Moreover the developing nations faced more complex problems in realising a stable identity because the legacy of colonial rule (Curle, 1971, p. 40). Rather than modernising too slowly it was suggested, 'the developing nation may destroy too rapidly various traditional forms of integration and unleash explosive levels of unrest' in its bid for modernisation (Smelser, 1966, p. 130). In summary, it was feared that, 'Modernization along broadly capitalist lines tends to produce a highly restless, insecure population' (Berger et al, 1974, p. 123). But even before alarm over Third World development became manifest, Western concerns over the direction of their own societies cast doubt on international modernisation strategies. 
The problems of the 'affluent society' whose technological advancement had made the work of millions redundant loomed large (Galbraith, 1962). Economists argued for policies maintaining employment when production, it was argued, was becoming important for employment rather than for the goods themselves and warned against not addressing the risks of nervous breakdown (Keynes, 1931). The psychological not just the financial consequences of being deprived of employment were extensively discussed. Intellectuals such as Hannah Arendt were concerned that the emancipation of labour was not ushering in an age of freedom or nourishing higher activities but more consumption: 'the more time left to him, the greedier and more craving his appetites' (Arendt, 1998, p. 133). 'Man [...] must be adapted to leisure, and his work must become occupational therapy' it was argued (Gabor, 1964, pp. 108-109, emphasis added). These debates may have had little impact on Western domestic production, but did influence how policy-makers thought about strategies for international development. Employment was put forward as the goal of international development (Galbraith, 1964, p. 9; ILO, 1969, 1976), deprioritising technological investment and encouraging policies for labour retention.

Events within Western societies in the 1960s reinforced alarm over modernisation's course. Civil disturbances, political assassinations, urban riots and youth disaffection challenged the efficacy of engineering consent through consumerism. The major US national inquiries into civil unrest had ramifications for international development thinking. Domestic debates reinforced fears that urbanisation fostered ghettos of mass poverty, alienation and political instability. Urban poverty may have been regarded by the urban poor as a step up from rural poverty (Galbraith, 1979, p. 51), but policymakers were nervous about its social effects, renewing their interest developing the rural economy and stemming the flow of migration (Kerner Commission, 1968, p. 236). Employment generation policies gave more attention to self-development and how to support people developing 'their own capabilities', including counselling in relation to the 'willingness to work' (ibid., p. 223, p. 315). In short, the psychology of the unemployed gained new interest.

Attention towards the psychology of the poor was reinforced by another theme, namely that the sources of insecurity and violence could be found within the self. As the National Commission on Violence argued, 'we must look inward as well as outward to the causes and prevention of violence' (National Commission on Violence, 1969, pp. 210-11). Civil violence was linked by US government advisers to the 'revolution of rising expectations' backfiring and creating frustration (Kerner Commission, 1968, p. 106). Both the Kerner Commission and the National Commission on Violence highlighted how too high expectations of what society could do had intensified dissatisfactions and fuelled the riots (ibid., p. 106). The National Commission on Violence argued that, 'a rapid increase in human expectations followed by obvious failure to meet those expectations has been and continues to be a prescription for violence' (National Commission on Violence, 1969, p. 41). Galbraith had already warned against the prevailing 'divine' doctrine, as he characterised it, that increased consumer production was 'the great solvent of tensions associated with inequality' (Galbraith, 1962, p. 86). If the production of many goods was unnecessary, save as a means of employment, consumerism was an insecure basis for building civic loyalty, Galbraith argued. An economy increasingly geared towards non-essential consumer production and dependent on consumer indebtedness, he 
warned, would foster economic instability and employment insecurity. Moreover Galbraith contended that increased producing was merely creating 'a higher level of want creation necessitating a higher level of want satisfaction' (ibid., p. 136). The inference drawn was that more attention should be paid to the subjective aspects of poverty, not just its objective aspects. Tellingly the Kerner Commission emphasises relative poverty rather absolute poverty as causing the grievances behind the violence. The idea that the new social violence arising in Western societies was a 'product of prosperity' (Crosland, 1961), and not simply poverty, was discussed across the Atlantic too.

Industrialisation of developing countries, supported where compatible with Western security interests, was cast into doubt when the process seemed to threaten those security interests. As one study observed, 'there is a widespread and [...] increasing linkage between modernization and the rise of social dissatisfaction and revolutionary consciousness' (Berger et al, 1974, p. 122). Civil unrest domestically and internationally, the Vietnam War, population growth in the South and the international oil crisis in which non-Western states were seen capable of holding Western states to ransom, together contributed to an incremental retreat from modernisation strategies in Western development thinking from the late 1960s onwards.

\section{Frustrating development}

The new Western development thinking took up the idea that expectations and wants needed to be moderated in the developing world too for the sake of international peace and security. Development thinking evolved a needs-based approach informed by the psychologist Abraham Maslow's theory of frustration. E.F. Schumacher's seminal work Small is Beautiful rejected modernisation strategies and called for moderating wants, arguing that raising material aspirations was no recipe for international security:

the foundations of peace cannot be laid by universal prosperity, in the modern sense, because such prosperity, if attainable at all, is attainable only by cultivating such drives of human nature as greed and envy (Schumacher, 1973, p. 28).

To the spectre of disorder was added the spectre of ecological crisis as Malthusian fears re-surged, especially following the oil crisis and Western panic over access to raw materials in the Third World. Furthermore, modernisation was attacked as corrupting humanity and leading to the moral impoverishment of people's lives. Schumacher's work condemns human hubris in seeking to transcend nature and expresses a desire to return to a simpler, more spiritual way of life, more tied to nature. These ideas echo Romantic thought and its attacks on the soulless character of modernity and compliments anthropological research inspired in part to recover alternative ways of life by studying indigenous populations least tainted by modern life. In this critique, the undeveloped world becomes a moral exemplar for the developed world.

Mainstream arguments were paralleled in Western radical thought, increasingly averse to the Soviet model, particularly after the Soviet invasion of Czechoslovakia, 
and trying to grapple with failure to mobilise a mass radical movement. Herbert Marcuse's One Dimensional Man, which acquired a cult following among radical circles of the late 1960s, attacked western consumer culture as creating false needs and anaesthetising individuals' consciousness against society's wrongs. Marcuse importantly argued that only those outside the industrial productive processes had the psychic integrity to rebel. 'Liberation from the Affluent Society', another of his works proclaimed (Marcuse, 1968). Marcuse, like Galbraith, did not dismiss the material needs of people in developing countries, nevertheless, these anti-modernisation ideas became applied to thinking about the problems of developing countries. Adam Curle, who founded peace studies at Bradford University, for example, deplored how 'many men's ambitions have been ensnared by the West and they have adopted many of its techniques and values' (Curle, 1971, p. 39). Curle further contended that, 'the actual efforts made to achieve development, which is supposed by some to reduce violence, can themselves be a source of violence' (ibid., p. 78). Hence there was a convergence of Western thinking questioning the wisdom of industrialisation and the existing modernisation strategies and seeking to relativise development, although still seeking to universalise its post-industrial civic norms. These perspectives were institutionally reinforced by the development of an international non-governmental aid sector fostered by Western donor preference for technical assistance to the developing world, and the switch of official aid from bilateral to NGO aid.

By the mid-1970s it was evident that the thrust of official international thinking was turning against transforming the means of production and re-orientating around securing the basic needs of populations, primarily through policies maintaining labour-intensive production. The new sustainable development thinking condemned the nascent industrialised wage economies as causing terrible social disruption and misery, rather than reducing poverty. Capital-intensive industrial production was criticised for creating unemployment and as being more exploitative than the older pre-industrial forms because of eroding small-scale dispersed ownership and concentrating the ownership of the means of production (Sen, 1975, p. 38). Mindful of industrialisation's risks, the ILO proposed an investment shift 'from physical to human capital, from urban to rural development, from capital-intensive to labourintensive activities, and from the production of non-essential consumer goods to essential ones' (ILO, 1976, p. 7). The ILO's World Employment Programme set out 'the promotion of employment and the satisfaction of the basic needs of each country's population' as 'a priority objective' (para 49 in ILO, 1977, p. 10). Policies such as tractorization were rejected for intermediate technology (Sen, 1975, pp. 154164).

Retaining labour-intensive production became a core strategy of international development. As part of this strategy, there was a new interest in self-employment and family labour to generate employment (ibid.). Non-wage employment generation was attractive because it would build on family and communal networks, and therefore help maintain social stability, rather than disrupt them as industrialisation policies had. Equally non-wage employment generation was attractive because it was regarded as not subject to the same vagaries of an economy (and employment) based on non-essential consumer production, as Galbraith had warned against in his critique of the affluent society. Non-wage employment generation would also help keep wants moderate and contain non-essential consumer production (ibid., p. 94). 
Yet the sustainable development model in rejecting advancing the means of production recoils from substantial material and social transformation. Its thinking consciously seeks to highlight problems of social exploitation and empower the poor in codifying basic needs as rights. Nevertheless the sustainable development model actually breaks the linkage between material and social progress made by earlier thinking, whether capitalist or Marxist inspired theories. Its understanding has moved away from a social structural approach towards an approach directed towards changing people's subjectivity and relations at the micro level to improve society. Accordingly structural problems are not understood in terms of the mode of production but are also naturalised or understood in social psychological terms. Sustainable development thinking emphasises limits to growth and naturalises underdevelopment, although the spectacular growth of China and other Asian countries in recent years belies such assumptions. The model implies people's lives will continue to be dominated by necessity and at best implies a fairer distribution of poverty. Tellingly the World Bank's Voices of the Poor report, discussed below, emphasises how the poor express very moderate needs (Narayan et al, 2000a, 2000b). Leaving aside important methodological issues as to how its policy conclusions could be reached (Pender, 2002), its recommendations demonstrate a very different international development agenda from that of the pioneering development period which wanted to shake the 'equilibrium of poverty' and encourage the poor to aspire to substantial material improvement. Since international development merely aspires to a labour-intensive, self-employment economy the majority of the world's population is destined for subsistence living. In other words, international development now resembles a self-help survival strategy for populations rather than truly a development policy.

Reducing development to survival strategies has severe ramifications for developing states. The approach both legitimises populations in the developing world having a lower standard of living and also limits what a developing state can offer its population in terms of social goods, as earlier development thinking accepted (Galbraith, 1979, p. 11). For a non-wage-based economy orientated around survival neither builds a national economy, nor a developed state infrastructure that could distribute social goods. Unsurprisingly hostility towards the new development thinking and its retreat from industrialisation was expressed by developing countries, which voiced mistrust over the basic needs concept after some initial support Aspelagh, (1979, p. 404). Hostility at the implied perpetuation of international inequality between the developed and developing world is evident in responses to the ILO's World Employment Programme (ILO, 1977, p. 13). So although developing countries strongly criticised Western modernisation models and denounced inequitable terms of trade, their criticisms did not amount to a rejection of industrialisation per se. Take the famous UN General Assembly 1974 Declaration on the Establishment of a New Economic Order sponsored by Non-Aligned Movement states. This declaration like so many UN declarations had little practical effect in changing international relations. Nevertheless it did articulate developing countries' aspirations for industrialization and modern technology as part of 'accelerating the development of developing countries'. However, the governments of developing countries' views progressively carried less weight: their weak capacity undermining their political legitimacy and encouraging more repressive rule, in turn eroding their moral legitimacy to represent their populations both domestically and internationally. 
The end of the Cold War finally eroded the international space that the developing countries had carved out for themselves amid East-West rivalry.

\section{Therapeutic governance}

Fundamental contradictions exist in the radical post-development agenda, which seeks transformation of relations along the lines of post-industrial societies without substantial economic transformation. These fundamental contradictions are possible because of its rejection of raising material expectations and its psychologised understanding of justice and its conception of social transformation in terms of psychosocial change. An emphasis on psychological needs has long been apparent in peace and development education (Aspelagh, 1979; Burns and Aspelagh, 1996), but development policy too increasingly conceives needs in psychological rather than material terms. Development's therapeutic turn parallels trends in Western domestic social policy giving new attention to the subjectivity of the poor and unemployed in which the psychosocial concept of social inclusion has displaced that of social equality. In the social inclusion model, low self-esteem is seen not just as an aspect of poverty but becomes its substantial meaning, while social recognition of the poor as opposed to the eradication of poverty has become the meaning of justice. Development becomes a form of therapeutic governance focused on enhancing people's capacities, motivation and sense of well-being within their existing material circumstances.

The World Bank's Voices of the Poor report has been heralded as a groundbreaking approach with its participatory methodology, analysis and methodology, signalling a new inclusive course for development policy that takes the personal experience of the poor as its starting point. The authors' put forward its methodology as a radical departure, but its approach essentially abandons social theory for an intuitive understanding of society. Analysis of the feelings, interpersonal relationships and daily interactions of the poor becomes translated into strategies seeking to manage the feelings, interpersonal relationships and daily interactions of the poor. In other words, the report exemplifies how development policy is now influenced by a psychological understanding and conceive social transformation and social justice in psychological terms. Effectively the onus is on households to access opportunities and secure their own welfare rather than the state. Thus the report suggests that interviewees' expectations that the state solve their problems is linked to a dependency culture and New Deal-type mass employment schemes are not considered as a policy option (Narayan, et al, 2000a, p. 62). Instead the report proposes that social change be achieved through a chain reaction of personal transformation:

Change is brought about by individuals in interaction with other individuals, one step at a time. Hence individual commitment, values, and behaviour matter and can be the most potent sources of change as committed individuals interconnect (ibid., p. 227).

Thus in so far as the state's role is considered in the lives of the poor, the report tends to focus on reforming institutional norms to stamp out corruption and ensure officials do not humiliate the poor and are more respectful to them.

The report demonstrates how a therapeutic concept of well-being is displacing 
universal prosperity as the goal of international development policy. The World Bank proposes that 'Well-being and illbeing are states of mind and being. Wellbeing has a psychological and spiritual dimension as a mental state of harmony, happiness and peace of mind.' arguing moreover that 'Wealth and wellbeing are seen as different even contradictory' (Narayan et al, 2000b, p. 21). The report's emphasis on the psychological dimensions of poverty is declared to derive from the poor's own definitions of poverty. Yet a closer examination of the final report along side the individual country findings suggests that the authors' construction of the interviews and selection of extracts are used to endorse a pre-existing policy agenda abandoning substantial material transformation (Pender, 2002). Interviewees, for example, speak of how unemployment makes them depressed. This observation is then used by the authors to support the idea that depression is hindering people from finding employment (Narayan et al, 2000b). The World Bank's approach has been taken up in official policies. DFID, for example, has closely associated itself with the Voices of the Poor report. Former development minister Clare Short wrote the foreword to the report. DFID held workshops for its staff on the report. The department too is showing a new concern for mental health, and has recently commissioned research on mental health in developing countries, linking poverty to mental health problems.

Fostering self-esteem is also now a core theme of international development strategies. Sen's influential writing, for example, has drawn attention to people's subjective experience of their circumstances, suggesting policies orientated towards improving people's self-esteem, how they feel about themselves and their work. Sen emphasises employment as providing self-esteem as well as income rather than production (Sen, 1975, p. 5). He is troubled by definitions of employment excluding many non-wage income generating activities people are involved in and therefore fail to give people recognition in their work. Consequently he argues for changing how certain work is viewed, 'Unemployment is a state of being without fruitful work and the perception of fruitful work is, to a large extent, a result of social conditioning' (ibid., p. 40, emphasis added). The strategy involves therapeutically re-describing as employment casual activities such as street hawking that economists previously regarded as hidden unemployment. Indeed Sen admits how previous economic thinking considered such non-wage labour disparagingly as self-help survival strategies (ibid., p. 4, p. 45).

In its flight from materialism, development thinking evades how poverty is to be eradicated and basic needs are to be realised in the absence of national economic development supporting the development of a modern state. The redistributive welfare state was preceded by industrial development which fostered an impersonal public sphere and the necessary infrastructure to make redistribution a possibility (Weber, 1954). Otherwise people will continue to rely on nepotism, that is, their informal networks to secure their needs and ambitions, militating against the eradication of corruption and the development of an efficient bureaucracy (Lipset, 1959, p. 66), which the World Bank seeks. Indicatively perhaps, the Voices of the Poor report speaks of 'the collective good' being achieved through 'personal commitment' creating 'small miracles' (Narayan et al, 2000a, p. 227).

Unrealisable without a developed state, promoting basic needs as rights works at the psychological level, giving symbolic moral recognition of the poor to the poor and the rest of society. This symbolic recognition, or statement of moral commitment, it is 
hoped, will foster their self-esteem, thereby empowering them with the confidence to act to secure their own needs. Recognition is also seen as advancing social inclusion and undermining alienation, which could foster social instability (Burton, 1997, p. 31). Underscoring the influence of psychological theories on frustration, fostering self-esteem does not imply raising aspirations. Rather tackling low self-esteem concerns tempering frustration, not firing ambition. Accordingly although the Voices of the Poor report speaks of its research method empowering participants and leading to 'follow-up action', it quickly warns against raising false expectations among participants (Narayan et al, 2000a, p. 16, p. 24). The ideal personality is far from the ambitious masculine moderniser. Male psychology is portrayed negatively in the report and characterised by frustration and aggression. The authors repeatedly highlight men's personalities as dysfunctional, and women's personalities as better able to cope with insecurities and provide for their families:

Many men are collapsing, falling into domestic abuse and violence [...] Women, on the other hand, seem to swallow their pride and hit the streets to do demeaning jobs to bring food to the family table (ibid., p. 219).

Thus gender policies are also underpinned by concerns to contain frustration and antisocial responses to insecurity. Accordingly policy seeks to empower the female personality against the male personality as a more appropriate personality to secure sustainable households and communities. In sum, international development as therapeutic governance proposes emotional adjustment for societies as material progress has been abandoned as unrealisable and destabilising, while their relationships are judged wanting by affluent post-industrial norms and requiring external management.

Effectively, therapeutic governance condemns the norms of the traditional economy, while condemning people to that very means of existence. Thus the Voices of the Poor report requires relationships within the household to change substantially, and face 'up to pervasive gender inequalities' (ibid., p. 226), even as its understanding of social justice does not propose to eradicate the substantial material inequalities between the developing and developed world. However, the rather conservative nature of international development as therapeutic governance is mystified by apparently radical references to empowerment. With the World Bank's satisfaction at finding the poor want so little, one might recall Galbraith's critical words on affluent countries long using 'the contentment of the poor as the justification of the existing order: "They are happy, poor things"” (Galbraith, 1979, p. 6).

\section{From national development to human security}

It is arguably a misnomer to speak of international development when development policy no longer aspires to material transformation and is orientated around survival and preventing frustration, that is, a soft security programme. Indeed the overlap between the current meaning of development and the concept of human security has been remarked upon (Mack, 2004, p. 50). If human security means freedom from fear and want, it is not evident how a development model orientated around limiting wants, satisfying basic needs, and preventing frustration aspires to anything beyond the security agenda. Since international development now offers so little materially to populations globally, its continuing existence may perhaps better be understood as 
addressing the therapeutic needs of the international community to feel a sense of moral purpose. To paraphrase the Voices of the Poor report on the importance of maintaining the poor's sense of cultural identity, maintaining a development agenda helps international officials 'to continue to believe in their own humanity despite inhuman conditions' (Narayan et al, 2000a, p. 7). The development sector may have seen the concept of human security as helping them tap into the greater resources enjoyed by the security sector (King, and Murray, 2001-2002, p. 589; Mack, 2004, p. 49). However, development has effectively become harnessed to a security agenda rather security becoming harnessed to a development agenda. The securitised development agenda represents a demoralised project. Human security's appeal among the international development sector as a progressive agenda (Suhrke, 1999, p. 264) simply illustrates how far developmental aspirations have fallen and the sector's loss of belief in both development and the developing state. A critical reading of human security's appeal suggests how the concept has sugared the pill of development sector's loss of its previous independence and its absorption into security policy. Thus human development or human security indices inform security risk analysis, rather than reinvigorating an ambitious international development project aspiring to universal prosperity.

Today's anti-development development model has far-reaching consequences for the position of developing states within the international order and their relation to their societies. Current development strategies have abandoned aspirations for securing the capacity of developing states and their equality with developed states, that is, abandoning economic advancement entails abandoning the aspiration for international equality and acceptance of inequality between states. In short, developing countries are destined to stay 'quasi-states' (Jackson, 1990): states nominally sovereign but lacking the capacity domestically to guarantee social justice and welfare for their populations, and lacking the capacity internationally to ensure they were treated as equals with the developed states. Here we come to the other side of human security: its military humanitarian agenda arising logically from the changed international development agenda. Namely humanitarian intervention compliments the erosion of the developing state's capacity in its challenge to the political sovereignty of the developing state.

The postwar international security system based on the principles of national security and the principle of non-interference in the affairs of states was premised on states having the capacity to guarantee their own security. Thus the international security system was dependent on developing the newly independent states. This collective security model becomes untenable without national development. So whereas the newly independent states looked forward to securing their capacity in the early heady days of international development, incapacity has become an indefinite condition for many states following international development's demise. The international division has widened between developed states with the capacity to guarantee their own security and developing states lacking capacity. This phenomenon is also represented as a moral division between responsible enforcing states and failing violating states whose populations need to be protected by the international community of responsible states. Hence the concept of human security encapsulates both the changed development agenda and the changed international security agenda which has shifted from a Realist security system to a system of global governance managed by the major powers and guided by risk analysis. 
However, global governance contains serious contradictions, which undermine its capacity to provide global security. Global governance by-passes the developing state to assume a more direct relationship with developing populations, even as it assumes continuing material differences between developed and developing world. Yet without national development, populations' expectations are no longer orientated within a national project, but become globalised under global governance. In Zaki Laidi's inspired analysis of globalisation, populations within a 'world social system' are encouraged to 'have the feeling of living in real time with the rich peoples of the North', and thereby compare their lifestyles, making them 'more reluctant to accept the values of patience' (Laidi, 1998, p. 49). The unintended consequence of global governance is to fuel negative comparisons and feed frustrations, rather than 'giving long-distance education on moderation' (ibid, p. 49). Consequently, human security, as a model of global governance, needs to re-assert cultural differences between people to legitimise its distinct visions for populations in the developed and undeveloped world, rather contradicting claims to speak for a common humanity.

Ironically the Cold War security framework provided greater scope than today for international development to forge a path distinct from security policy. The concept of human security does not represents a progressive agenda, but accepts a world in which underdevelopment and inequality between states and differences between populations are re-naturalised. Earlier development thinking was preoccupied with 'attacking accommodation' and breaking 'the equilibrium of poverty' (Galbraith, 1962, p. 64). However, accommodation appears to be the goal of today's securitised development policy, wary of advancing production and raising material aspirations. Yet I suggest serious contradictions exist in the human security model of global governance. Not least legitimising far-reaching global interventions, encompassing the very subjectivity of populations, clashes with the desire to contain expectations among populations and discourage population movement through fostering selfsustaining communities. The contradiction between radical intervention and the containment of expectations and population movement is hardly a recipe for social stability globally. The contradictions of human security are only reconcilable in so far as the concept remains a rhetorical appeal to rally a demoralised development community or to legitimise security policy among a traditionally hostile audience. The concept of human security embodies neither a viable development policy nor a viable security policy.

Note: I would like to thank Anthony Forster and Mark Duffield and the anonymous for their encouraging critical comments and advice. Please note this is an non-proofed version of the final article.

\section{References}

Arendt, H., 1998. The Human Condition. Chicago University Press, Chicago and London.

Aspelagh, R., 1979. 'Basic Needs and Peace Education.' Bulletin of Peace Proposals 10(4), pp. 403-14. 
Axworthy, L., 1999. 'An Address On Human Security', Minister Of Foreign Affairs, To The G-8 Foreign Ministers’ Meeting, 9 June.

Benedict, R., 1961. Patterns of Culture. Routledge, London.

Berger, P.; Berger B. and Kellner H., 1974. The Homeless Mind: Modernization and Consciousness. Penguin, Harmondsworth.

Bernays, E., 1956. Engineering of Consent. University of Oklahoma, Norman.

Burns, R. and Aspelagh R., 1996. 'Peace Education and the Comparative Study of Education', in Burns, R. and Aspelagh, R., (eds), Three Decades of Peace Education Around the World. Garland Publishing, New York and London, pp. 3-23.

Burton, J., 1997. Violence Explained: the sources of conflict, violence and crime and their provention. Manchester University Press, Manchester.

Canadian Department of Foreign Affairs and International Trade (1999) Human Security: Safety for People in a Changing World. Toronto, April. http://www.summitamericas.org/Canada/HumanSecurity-english.htm

Cowen, M. and Shenton, R., 1995. 'The Invention of Development', in Crush J. (ed.) The Power of Development. Routledge, London.

Crosland, A., 1961. 'Patterns of Revolt.' New Statesman, 6 October.

Curle, A., 1971. Making Peace. Tavistock, London.

Dollard, J et al, 1939. Frustration and Aggression. Yale University Press, New Haven.

Duffield, M., 2001. 'Governing the Borderlands: Decoding the Power of Aid', Disasters 25(4): 308-320.

Etzioni, A., 1962. The Hard Way to Peace: A New Strategy. Crowell-Collier Press, New York.

Furedi, F., 1997. Population and Development: A Critical Introduction. Polity, Oxford.

Furedi, F., 1998. The Silent Race War: Imperialism and the Changing Perception of Race. Pluto, London.

Gabor, D., 1964. Inventing the Future. Penguin, Harmondsworth.

Galbraith, J.K., 1962. The Affluent Society. Penguin Books, Harmondsworth.

Galbraith, J.K., 1964. Economic Development. Harvard University Press, Cambridge, Mass. 
Galbraith, J.K. (1979) The Nature of Mass Poverty. Harvard University Press, Cambridge, MA and London.

Y Gasset, J. O., 1961. The Revolt of the Masses. Allen \& Unwin, London.

LeBon, G., 1995. The Crowd: A Study of the Popular Mind. Transaction Publishers, New Brunswick, N.J.

Ginsburg, N., 1966. 'The City and Modernization', in Weiner, M. (ed.) Modernization: The Dynamics of Growth. Voice of America Forum Lectures, Washington, DC, pp. 133-148.

Herman, E., 1995. The Romance of American Psychology: Political Culture in the Age of Experts. University of California Press, Berkeley.

Ikeles, A. and Smith, D.H., 1974. Becoming Modern: Individual Change in Six Developing Countries. Harvard University Press, Cambridge MA.

ILO, 1969. The World Employment Programme. Report of the Director General of the ILO (part 1) to the International Labour Conference. ILO, Geneva.

ILO, 1976. Employment Growth and Basic Needs: One World Problem. Report of the Director General of the ILO. ILO, Geneva.

ILO, 1977. Meeting Basic Needs: Strategies for eradicating mass poverty and unemployment, Conclusions of the World Employment Conference 1976. ILO, Geneva.

Jackson, R., 1990. Quasi-States: Sovereignty, International Relations and the Third World. Cambridge University Press, Cambridge.

Keynes, J.M., 1931. 'Economic Possibilities for Our Grandchildren' in Essays in Persuasion. Macmillan, London.

King, G. and Murray C., 2001-2002. 'Rethinking Human Security.' Political Science Quarterly, Vol. 116, No. 4, pp. 585-610.

Kornhauser, W., 1960. The Politics of Mass Society. Routledge and Kegan Paul, London.

Laidi, Z., 1998. A World Without Meaning: the crisis of meaning in international politics. Routledge, London and New York.

Lipset, S., 1959. Social mobility in industrial society. University of California Press, Berkeley.

Mack, A. 2004. 'The Concept of Human Security', in Michael Brzoska and Peter J. Croll (eds) Promoting Security: But How and For Whom? Bonn: Bonn Center for Conversion (BICC), pp. 47-50. 
Marcuse, H., 1964. One Dimensional Man: Studies in the Ideology of Advanced Industrial Society. Routledge \& Kegan Paul, London.

Marcuse, H., 1968. 'Liberation from the Affluent Society', in Cooper D. (ed.), The Dialectic of Liberation. Penguin, Harmondsworth, pp. 175-192.

Maslow, A., 1970. Motivation and Personality. Harper \& Row,New York.

McClelland, D.C., 1961. The Achieving Society. Van Nostrand, Princeton, N.J. and London.

Obuchi, K., 1999, Prime Ministerial Address, 'In Quest of Human Security', Japan Institute for International Affairs 40th Annual Symposium, United Nations University, Tokyo, 11 December.

Narayan, D. with Patel, R.; Schafft, K.; Radenmacher, A. and Koch-Schulte, S., 2000a. Voices of the Poor: Can Anyone Hear Us? Oxford University Press, Oxford.

Narayan, D, ; Chambers, R.; Kaul Shah, M. and Petesch, P., 2000b. Voices of the Poor: Crying Out for Change. Oxford University Press, Oxford.

National Commission on the Causes and Prevention of Violence, 1969. Report of the National Commission on the Causes and Prevention of Violence To Establish Justice, To Insure Domestic Tranquillity. U.S.G.P.O, Washington D.C.

National Advisory Commission on Civil Disorders (Kerner Commission), 1968. Report of the National Advisory Commission on Civil Disorders. Bantam Books, New York.

Nelson, J.M., 1969. Migrants, Urban Poverty, and Instability in Developing Countries. Occasional Papers in International Affairs, No. 22. Center for International Affairs, Harvard University.

Pender, J., 2002. 'Empowering the Poorest?: The World Bank and "The Voices of the Poor"' in Chandler D. (ed.) Rethinking Human Rights: Critical Approaches to International Politics. Palgrave, Basingstoke, pp. 97-114.

Rostow, W.W., 1960. The Stages of Economic Growth: A Non-Communist Manifesto. Cambridge University Press, London.

Rostow, W.W., 1971. Politics and the Stages of Growth. Cambridge University Press, London.

Schumacher, E.F., 1973. Small is Beautiful: A Study of Economics as if People Mattered. Blond \& Briggs, London.

Sen, A., 1975. Employment, Technology and Development. Clarendon, Oxford. 
Smelser, N., 1966. 'The Modernization of Social Relations', in Myron Weiner (ed.) Modernization: The Dynamics of Growth. Voice of America Forum Lectures, Washington, DC.

Suhrke, A., 1999. 'Human Security and the Interests of States.' Security Dialogue, Vol. 30, No. 3, September.

UNDP, 1994. Human Development Report 1994: New Dimensions of Human Security. UNDP, New York.

UN General Assembly, 1974. Declaration on the Establishment of a New Economic Order. A/RES/3201. http://www.un.org/Depts/dhl/resguide/resins.htm

UNICEF, 1964. Children of the Developing World. William Clowes, London.

Wood, R., 1966. 'The Future of Modernization', in Myron Weiner (ed.) Modernization: The Dynamics of Growth. Voice of America Forum Lectures, Washington, DC, pp. 43-55.

Weber, M., 1954. in Rheinstein M. (ed.) Max Weber on Law in Economy and Society. Simon \& Schuster, New York.

\footnotetext{
${ }^{1}$ Many of the reports on human security are available on the internet. There are also a number of useful web sites providing information on human security sources. One informative site is sponsored by Harvard University, including a detailed bibliography on human security: http://www.hsph.harvard.edu/hpcr/events/hsworkshop/bibliography.pdf
} 